\title{
Silicon in the morphometry and germination of corn seeds for silage
}

Kathery Brennecke ${ }^{1}$

Letícia Sarro²

Paulo Henrique Moura Dian³

Maria Helena Ferrari ${ }^{4}$

Liandra Maria Abaker Bertipaglia 5

Weberson Donizete de Castro Amancio ${ }^{6}$

\section{Abstract}

As a forage, the objective of this study was to evaluate corn plant, seed development and seed germination in response to silicon application at different doses pathway leaf. The experimental design was randomized blocks with four treatments of different doses of silicon, equivalent to 0.0, 100.0, 200.0 and 300.0kg ha-1 of calcium silicate, at $22 \%$, and four replications, applied pathway leaf. It was observed that the applied silicon did not influence any of the plant morphometric variables, however it altered the ear characteristics regarding weight and diameter, at which the best response was observed in the application equivalent to $100 \mathrm{~kg}$ silicate ${ }^{-1}$ ha $^{-1}$. The applied silicon doses showed no significant differences in morphological characteristics such as plant height, first ear height, stem diameter, number, and leaf angles. Significant differences were found in the weight of one thousand grains, and by increasing the silicon dose, there was an increase in the weight of one thousand grains and in the germination; in 7 days, it was found a decrease in germination percentage as well as in the percentage of normal seedlings when increasing the calcium silicate doses. It was concluded that the application of calcium silicate via leaf increased the stem diameter, the ear of corn and the weight of one thousand seeds and decreased the germination percentage in seven days and the appearance of normal seedling.

Keywords: Beneficial element. Morphology. Plant's development. Zea Mays.

\section{Introduction}

Silicon is classified as an element that benefits plants; however, the context of good forage production must consider all essential mineral elements to the plant, as well as the benefits. Silicon is directly involved to the plant's physical functions, such as evapotranspiration regulation and physical barriers formation resistant to fungi invasion and bacteria inside the plants, besides it partially does not allow plagues attack (EPSTEIN, 2001; MELO et al., 2003; COSTA; COSTA, 2009).

1 Universidade Brasil, Campus Descalvado, Programa de Mestrado Stricto sensu em Produção Animal. Docente. kathery.brennecke@ universidadebrasil.edu.br. Avenida Hilário da Silva Passos, s/n. Jardim Universitário, Descalvado/SP, 13699-000. 
The silicon accumulation in the cuticle (epidermis) determines changes in the plants architecture, turning it more upright, what avoids lodging, the photosynthesis increase, resulting in more chlorophyll accumulation and, in plants of greener colors, it becomes more intense (KORNDÖRFER; DATNOFF, 2000).

This structural function provides anatomic changes in the issues, as epidermal cells with cell walls thicker due to the silicon deposition on them, and according to Blaich and Grundhofer (1998), mentioned by Pozza (2004), this condition is what favors the best architecture of the plant, the increasing of the photosynthetic capacity and resistance to plagues and diseases.

Ferreira (2006) states that silicon may be one of the reasons why dry matter increases, due to the greater photosynthetic activity it provides. In this case, the photosynthetic capacity of the plant can be increased by the greater absorption of silicon which improves the leaf architecture by increasing the capture of radiant energy.

Higher photosynthetic activity also occurs with the reduction of the distance between the plants, increasing the population density, which results in higher light interception. This can be obtained by a better spatial arrangement between the plants and the foliar area, increasing the area unit in initial phonological stages (MOLIN, 2000). The reduction of the distance between the plants limit weeds development, through the light's transmission reduction in the vegetal canopy (BALBINOT; FLECK, 2005).

On the other hand, according to Ribeiro et al. (2005), plants' density implements increase the culture's susceptibility to the lodging and stems breaking.

Based on that, this experiment is justified by working with the hypothesis that the triple crop of corn (BM 3061), which has high potential for silage production, planted in reduced spacing, may have its growth, in addition to changes in the ear of corn and in the germinative issue, influenced by the silicon fertilization. Therefore, the aim of this study was to evaluate the morphometric characteristics of the plants and corn cob and seed germination by the cultivator BM 3061, applying different doses of calcium silicate on its leaves.

\section{Material and methods}

The experiment was performed at the experimental field of the University Brazil, Campus Descalvado/SP, from January to April, with a variety suitable as both conventional maize and off-season.

Before the experiment performance, soil analyses at the deep of 0-20 cm was conducted to determine chemicals' characteristics. The results obtained were: phosphorus $4.0 \mathrm{mg} \mathrm{dm}^{-1 ;} 13.0 \mathrm{~g} \mathrm{~kg}^{-1}$ of $\mathrm{MO} ; 5.1 \mathrm{pH}$ in $\mathrm{CaCl}_{2}$; 3.0; 24.0; 8.0; 31.0; 7.8 mmolc dm ${ }^{-3}$ of $\mathrm{K}, \mathrm{Ca}, \mathrm{Mg}, \mathrm{H}+\mathrm{Al}, \mathrm{CTC}$, respectively, and $\mathrm{V} \%=53.0 \%$.

The pluvial data obtained during the experiment performance is shown in Table 1, characterized by a typical y corn cob in the region, in terms of weather and rainfall.

Table 1 - Rainfall data of the municipality of Descalvado/SP

Climatological Monitoring: Beginning of season: from 01/01/2006 to 14/09/2015 County: Descalvado/SP

\begin{tabular}{cccccccccccccc}
\hline Year & Jan. & Feb. & Mar. & Apr. & May & Jun. & Jul. & Aug. & Sep. & Oct. & Nov. & Dec. & Total \\
\hline 2014 & 59.1 & 48.9 & 135.3 & 42.0 & 52.8 & 4.3 & 30.3 & - & 71.7 & 21.4 & 211.8 & 170.9 & 848.5 \\
2015 & 173.7 & 256.2 & 146.5 & 71.1 & 83.6 & 35.4 & 52.7 & 10.7 & 119.4 & - & - & - & 949.3 \\
\hline Average & 116.4 & 152.55 & 140.9 & 56.55 & 68.2 & 19.85 & 41.5 & 10.7 & 95.55 & & & & \\
\hline
\end{tabular}

Source: CIIAGRO online. Disponível em: www.ciiagro.sp.gov.br. (2019). 
After that, the soil was corrected with $20.10 \mathrm{~kg}$ of limestone, that was applied and incorporated in the total area. After, parcels were divided. The experimental design was adopted in randomized blocks, in a total of 16 plots, with 4 replicates in each parcel, totaling 60 plants. The experimental plots consisted of 4 lines of 4.0 meters in length, and 4 meters in width $\left(16 \mathrm{~m}^{2}\right)$, considering the 2 central lines as useful area.

The crop fertilizing followed Raij et al. (1997) recommendation, adopting $66.34 \mathrm{~kg} \mathrm{ha}^{-1}$ of $\mathrm{N}$, 333.0kg ha-1 of $\mathrm{P}_{2} \mathrm{O}_{5}$, and $51.89 \mathrm{~kg} \mathrm{ha}^{-1}$ of $\mathrm{K}_{2} \mathrm{O}$. As source of $\mathrm{N}, \mathrm{P}_{2} \mathrm{O}_{5}, \mathrm{~K}_{2} \mathrm{O}$ and urea (45.0\% of $\mathrm{N}$ ), simple superphosphate $\left(18.0 \%\right.$ of $\mathrm{P}_{2} \mathrm{O}_{5}$ and $12.0 \%$ of $\mathrm{S}$ ) was used as well as potassium chloride $(60.0 \%$ of $\mathrm{K}_{2} \mathrm{O}$ ), respectively, and also it was applied $44.40 \mathrm{~kg} \mathrm{ha}^{-1}$ of $\mathrm{N}$ in cover, using urea as source $(45.0 \%$ of $\mathrm{N})$.

It was adopted a reduced spatial of $0.50 \mathrm{~m}$ between the lines and $0.25 \mathrm{~m}$ between the plants for the seedling, using a triple hybrid BM 3061 by Biomatrix.

The silicon source used was the calcium silicate which contains $22.0 \%$ of Si. The silicon doses were $0.0,60.0,120.0$ and 180.0g of silicon/parcel (equivalent to 0.0,100.0, 200.0,300.0kg of silicon per ha-1), in form of calcium silicate. For applying the silicon treatments, it was used a $10 \mathrm{~L}$ capacity costal pulverizer, with regulated flow in order to propose the same volume to each application.

The silicon application was conducted on cover via leaf when the plants were between the phenological development stage 2 ( $4^{\text {th }}$ leaf), according to Cruz and Turpin (1982), in the referred doses.

The following variables were evaluated: plant height and first corn cob insertion, both measurements occurred at the time of full flowering, and the distance between the soil surface and the floral tassel insertion of 32 plants was measured, the distance between ground surface and first corn cob insertion was also measured (DEMETRIO et al., 2008).

Leaf angulation was always measured below the corn cob in phase 4 of development, using a protractor, following the methodology of Freitas et al. (2011).

The stem diameter was measured from the first internode of the corn plant, which was about $5.0 \mathrm{~cm}$ above the ground, using a tape measure. The total number of leaves was counted at the time of complete flowering.

With the aid of a caliper, 6 corn cobs of each plot were measured to verify the diameter of the corn cob. Corn cob grains were counted by assessing the number of seeds in length (seeds per row) and then multiplying by the number of seeds in diameters (rows) (VAZQUES et al., 2012).

Corn cob weight was evaluated using a digital scale, six corn cobs from each plot were weighed.

The weight of one thousand seeds was determined using ten repetitions of 100 seeds for each treatment, weighed with a precision of $0.001 \mathrm{~g}$. The conduction of the test was according to Brasil (1999), and the average of the data was expressed in grams.

The germination test was conducted at a temperature of $20.0^{\circ} \mathrm{C}$ in a germination chamber. The readings occurred on the 4th and 7th days after the test facilities, considering the number of normal seedlings to determine the germination percentage according to the procedure established in the rules for seed analysis (BRASIL, 2009).

The data were submitted to the variance analyses, by regression test to the level of $1 \%$ probability, supported by ASSISTAT software version 7.7 (SILVA, 2009).

\section{Results and discussion}

Medium results to the plants morphometric variables found in the experiment is shown in Table 2, it can be noticed that there were not meaningful differences to the tested variables, when applied different doses of calcium silicate. 
Table 2 - Height of the plant, height of the first corncob $(\mathrm{cm})$, stem diameter $(\mathrm{cm})$, number of leaves $\left(n^{\circ}\right)$ and leaf angulation $\left({ }^{\circ}\right)$, as a function of $\mathrm{Si}$ applied via leaf.

\begin{tabular}{|c|c|c|c|c|c|}
\hline Treataments & Plant Height & $\begin{array}{c}\text { Corncob } \\
\text { Height }\end{array}$ & $\begin{array}{c}\text { Diameter of } \\
\text { the Stem }\end{array}$ & $\begin{array}{c}\text { Number of } \\
\text { Leaf }\end{array}$ & $\begin{array}{c}\text { Leaf } \\
\text { Angulation }\end{array}$ \\
\hline kg(ha & & $(\mathrm{cm})$ & & $\left(n^{0}\right)$ & $\left({ }^{\circ}\right)$ \\
\hline 0 & 118.88 & 64.25 & 6.25 & 10.12 & 35.62 \\
\hline 100 & 122.50 & 54.16 & 5.80 & 10.37 & 33.25 \\
\hline 200 & 121.38 & 51.19 & 6.37 & 10.00 & 36.75 \\
\hline 300 & 121.73 & 53.37 & 6.56 & 9.75 & 37.00 \\
\hline Linear Regression & $0.77^{\mathrm{ns}}$ & $3.96^{\mathrm{ns}}$ & $1.12^{\mathrm{ns}}$ & $0.18^{\text {ns }}$ & $0.36^{\text {ns }}$ \\
\hline Quadratic regression & $0.30^{\text {ns }}$ & $2.35^{\mathrm{ns}}$ & $0.97^{\mathrm{ns}}$ & $0.09^{\text {ns }}$ & $0.31^{\text {ns }}$ \\
\hline Coefficient of variation (\%) & 5.77 & 14.36 & 10.11 & 15.53 & 15.02 \\
\hline
\end{tabular}

${ }^{n s}$ not significant by the $\mathrm{F}$ test; ** significant at the $1 \%$ probability level $(p<.01)$; * significant at the $5 \%$ probability level $(.01=>p<.05)$.

Source: Elaborated by the authors (2019).

The present results of works carried out, in relation to the first corncob, corroborates the results of Freitas et al. (2011). On the other hand, Teodoro et al. (2014), when evaluating silicon doses via leaf, did not find meaningful results to that variable. Freitas et al. (2011), evaluating the plant's height and stem diameter applying silicon different dosage equivalent to 130.0, 260.0, 390 and $520.0 \mathrm{~g} \mathrm{ha}^{-1}$ of $\mathrm{S}$ (sulfur) via leaf, and in three different application season (plants showing 2, 5, and 8 expanded leaves), did not find out meaningful results to those variables. The same occurred to Teodoro et al. (2014), who evaluated the same variables, working with treatments constituted by the grouping of leaf fertilization with and without silicon, and eleven corn hybrids.

In relation to the stem diameter, it was not found meaningful statistic differences. These results corroborate the ones from Chaves and Vasconcelos (2006), who evaluating the stem diameter in the corn's culture under the effect of retorted schist $\left(57.0 \%\right.$ in weight of silicon dioxid $\mathrm{SiO}_{2}$, did not observe meaningful effects to that variable. On the other hand, Neri et al. (2009) observed an increase in the stem diameter of the corn's plant fertilized with silicon, and Medeiros et al. (2008) found out a reduction in sugar cane stem diameter fertilized with rising silicon dosage.

The silicon dosage did not influence the leaf number. In the literature, it is hard to find information on works carried out conducted with number of leaf in relation to the silicon fertilizing in the corn's culture; however, Camargo and Pereira (2003), working with applying calcium silicon with two sugar cane varieties, evaluating the number of leaves in initial and maximum growing periods, observed meaningful results.

The use of silicon has promoted improvement in the plants architecture and an increase in the photosynthesis (DEREN et al., 1994), resulted from a shorter leaf opening, leaves more upright, reducing the self-shading, especially in conditions of high population density and high nitrogen dosage (BALASTA et al., 1989); however, in this experiment, it was not observed meaningful differences related to the evaluation to the leaf angle to no tested dosage compared to the testimony.

According to Maddonni and Otegui (1996), the leaf angulation can vary among corn varieties in relation to characteristics of each genotype.

Applying silicon via Leaf causes some motivation in plants, such as more upright leaves, reduction in the shelf-shading and harder structure of the issues with the mechanic resistance increasing of the cells (FRANZOTE et al., 2005). 
Nunes et al. (2010), evaluating the foliar angulation and working with three facts (very earlier corn hybrids, space of 0.45 and $0.90 \mathrm{~m}$ between the corn lines, and the weeds control in post-corn emergency) did not find meaningful differences.

It was not observed bedding in any of the experiment parcels. According to Sagoi et al. (2002), a hybrid with less energy requirement for its flowering is less affected to the effect of the density for having a shorter stature and for having a shorter height of inserting the corncob that are characteristics responsible by the plant gravity center closer to the soil level, what contributes to the non-lodging.

The corn used in the experiment has very earlier corn characteristics and requires from 830.0 to 890.0 degrees-day, the least amount of energy that normal crops need.

The average results found in the corncob analyses, with weight and corncob diameter, a Thousand grains' weight, grains quantity, can be observed in Table 3.

Table 3 - Mean values for corn cob weight $(\mathrm{g})$, corn cob diameter $(\mathrm{mm})$, weight of one thousand grains $(\mathrm{g})$, quantity of grains.

\begin{tabular}{ccccc}
\hline Treatments & $\begin{array}{c}\text { Corncob } \\
\text { Weight }(\mathbf{g})\end{array}$ & $\begin{array}{c}\text { Diameter of } \\
\text { Corncob }(\mathbf{m m})\end{array}$ & $\begin{array}{c}\text { Thousand Grain } \\
\text { Weight }(\mathbf{g})\end{array}$ & $\begin{array}{c}\text { Number } \\
\text { of Grains }\end{array}$ \\
\hline 0 & 140.33 & 42.71 & 343.25 & 383.54 \\
100 & 160.57 & 46.71 & 361.65 & 421.62 \\
300 & 141.05 & 44.91 & 368.25 & 384.29 \\
Linear Regression & 131.13 & 42.83 & 385.10 & 379.66 \\
Quadratic regression & $3.9^{\text {ns }}$ & $0.32^{\text {ns }}$ & $29.36^{* *}$ & $0.83^{\text {ns }}$ \\
Blocks & $8.05^{*}$ & $9.39^{* *}$ & $0,02^{\text {ns }}$ & $3.16^{\text {ns }}$ \\
Coefficient of variation $(\%)$ & $1.64^{\text {ns }}$ & $0.62^{\text {ns }}$ & $0.34^{\text {ns }}$ & $2.60^{\text {ns }}$ \\
\hline
\end{tabular}

${ }^{n s}$ not significant by the $\mathrm{F}$ test; ${ }^{* *}$ significant at the $1 \%$ probability level $(p<.01)$; *significant at the $5 \%$ probability level $(.01 \geq p<.05)$. ns

Source: Elaborated by the authors (2019).

It were found meaningful differences $(p<0,05)$ when studied the corncob weight, at which the higher result was when applying $100.0 \mathrm{~kg}$ silicon per ha-1 ${ }^{-1}$ it is also observed that with the dose increasing, it occurred a tendency to reduce the corncob weight as it is demonstrated in Figure 1. 
Figure 1 - Mean values found for the corn cob weight (g) as a function of the applied silicon.

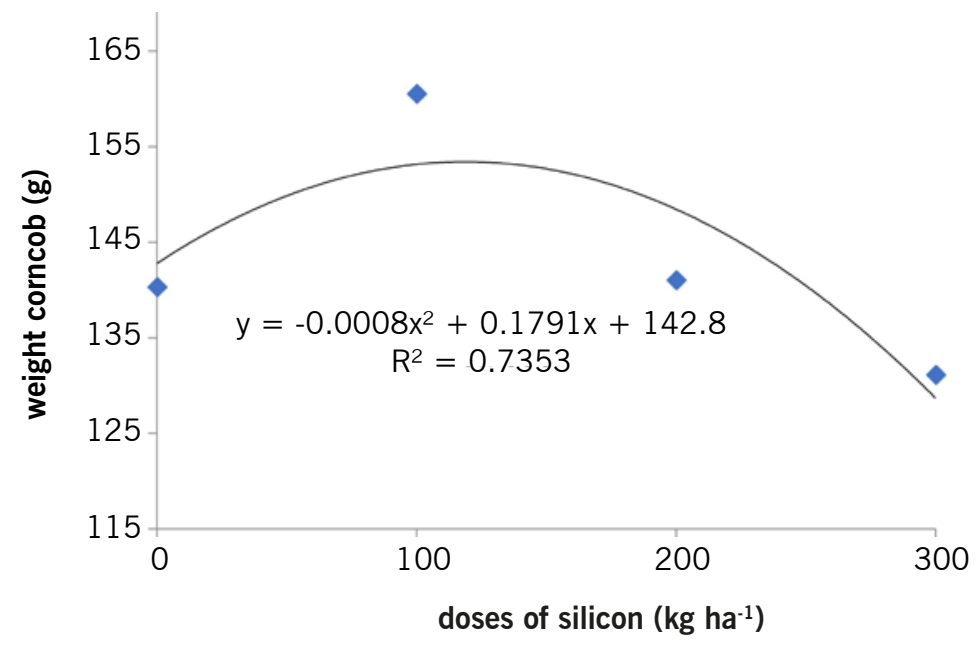

Source: Elaborated by the authors (2019).

By the technic of the quadratic function derivation, it was determined a great silicone dosage of $111.94 \mathrm{~kg} \mathrm{ha}^{-1}$, showing a reduction in function for the corncob weight.

Freitas et al. (2009) worked with the application of different silicon dosage, and they evaluated corncob parameters and did not find meaningful differences in terms of weight, what differs from this experiment. Therefore, the author used as silicon source the potassium silicate, which has $12.0 \%$ of silicon and $15.0 \%$ of $\mathrm{K}_{2} \mathrm{O}$. This experiment silicon source (Calcium silicate) has $24.2 \%$ of Si and $30.1 \%$ of $\mathrm{Ca}$.

It was observed a meaningful difference $(p<0,001)$ to the corncob diameter; by increasing the applied dosage, it was noticed a tendency to reducing the diameter, as demonstrated in Figure 2.

Figure 2 - Mean values found for the corn cob diameter $(\mathrm{mm})$ as a function of the applied silicon dosages.

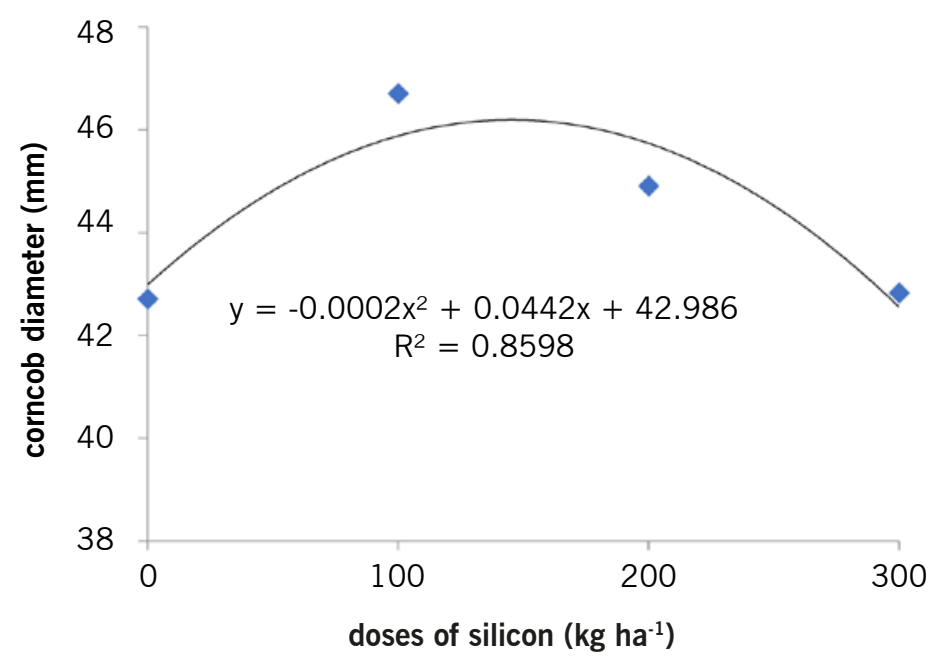

Source: Elaborated by the authors (2019).

In relation to the corncob diameter, it was observed by the derivation technic that the higher corncob diameter was due to $110.5 \mathrm{~kg} \cdot \mathrm{ha}^{-1}$ dosage. 
Freitas et al. (2009), while studying the corn corncobs behavior in function of the silicon leaf applied, did not find meaningful results to the length parameter and the corncob diameter.

The authors comment that during the experiment it was registered $1,429 \mathrm{~mm}$ of rain, and that this value is superior to the minimum required to maize cultivation ( $350 \mathrm{~mm}$ to $500 \mathrm{~mm}$ ), they attributed to this fact the failure to observe the significant effects, because it is considered that silicon shows up better in environments of stress to plants. In the present experiment, it was found out an accumulated $645.2 \mathrm{~mm}$ of rain, not distributed uniformly, and at the time of filling the grains, there was lack of water.

Marschner (1995) said that silicone provides some benefits to plants, for example, better photosynthetic efficiency, higher water use, and other benefits, so that it was expected higher grain filling to higher silicon doses, but it was not verified that effect.

When studying the weight of a Thousand grains, it was found out considerable statistic differences $(p<0,001)$; according to the silicon dosages applied, it was observed that increasing the dosages provided an increase in the weight of the one thousand grains evaluation, as shown in Figure 3.

Figure 3 - Average values found for the weight of one thousand grains ( $\mathrm{g}$ ) according to the applied silicon dosages.

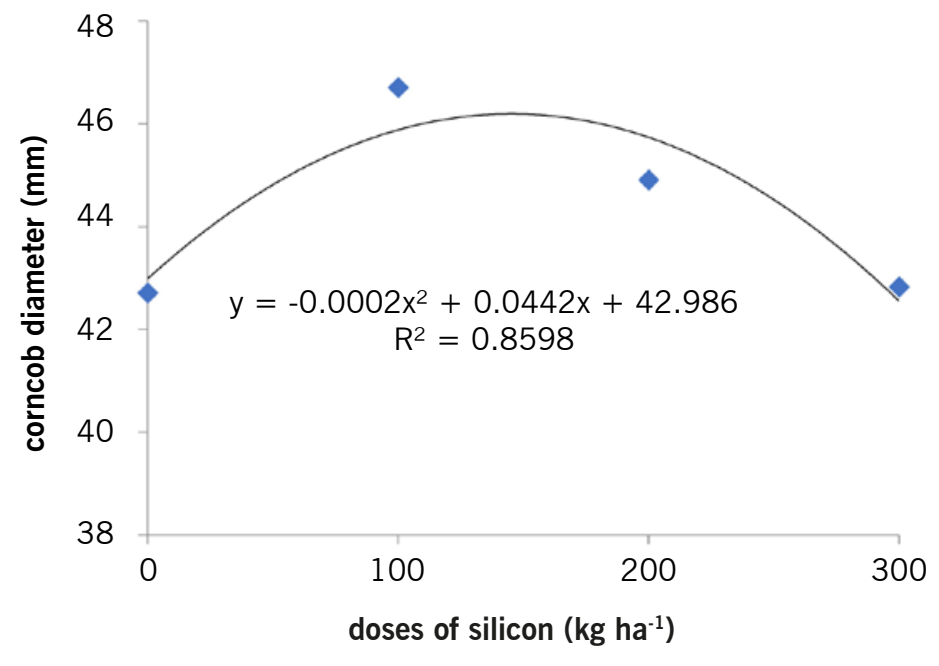

Source: Elaborated by the authors (2019).

It is observed that the data adjust to the linear model in $97.23 \%$, which means that the increase that occurs in a thousand grains weight can be explained by the variation in de calcium silicate doses.

Lima Filho and Tsai (2007) observed some benefits when they applied silicon in a white oat and wheat dough seed. When applying silicon dosages (0.0, 50.0, 100.0, 150.0, 200.0, 250.0, $300.0,350.0,400.0,450.0$ and $\left.500.0 \mathrm{~kg} \mathrm{ha}^{-1}\right)$ in the plantation furrows, by the soybean sowing, the treatments did not provide remarkable increases to the grains productivity, a thousand seeds weight and number of seed by legume.

Prado and Konrdorfer (2003) state that the absence of responses for the silicon applying can be related to either a low absorption or to a non-absorption of the element by the plantation.

According to Carvalho and Nakagawa (2000), the size of the seeds has strong effects in terms of plants initial growing, reducing this intensity as far as their development, in other words, big seeds are those which have higher storage nutrients quantity, for the development of the embryonic phase. 
Sousa et al. (2010) reported that silicon applied to the corn plant contributed to the mass of one thousand grains and increased productivity.

As demonstrated in Table 4, it was found considerable differences to the germination percentage to the 7 days and to the normal seedling percentage.

Table 4 - Mean values for germination percentage at 4 and 7 days, germination of normal seedlings.

\begin{tabular}{cccc}
\hline \multicolumn{1}{c}{ Treatments } & $\begin{array}{c}\text { Percentage of } \\
\text { germination at } \mathbf{4} \text { days }\end{array}$ & $\begin{array}{c}\text { Percentage of } \\
\text { germination at } \mathbf{7} \text { days }\end{array}$ & $\begin{array}{c}\text { Percent of } \\
\text { Normal Seedlings }\end{array}$ \\
\hline 0 & 98.16 & 99.16 & 84.33 \\
100 & 97.83 & 99.83 & 90.83 \\
200 & 96.83 & 97.83 & 83.16 \\
300 & 96.66 & 97.46 & 74.83 \\
\hline Linear Regression & $0.05^{\mathrm{ns}}$ & $6.40^{*}$ & $7.6^{*}$ \\
Quadratic regression & $0.50^{\mathrm{ns}}$ & $0.20^{\mathrm{ns}}$ & $6.4^{*}$ \\
Blocks & $0.31^{\mathrm{ns}}$ & $0.15^{\mathrm{ns}}$ & $1.4^{\mathrm{ns}}$ \\
Coefficient of variation (\%) & 1.94 & 1.11 & 7.04 \\
\hline
\end{tabular}

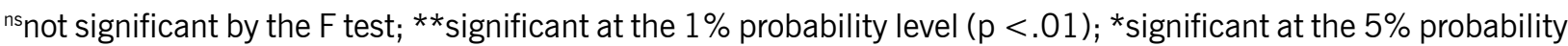
level $(.01=>p<.05) . n s$

Source: Elaborated by the authors (2019).

In relation to the germination tests, it was not found considerable differences in the evaluation after 4 days, but it was found considerable differences $(p<0,05)$ after 7 days of germination, at which it is observed a reduction in the germination with increase in the silicon doses as shown in Figure 4.

Figure 4 - Mean values found for the percentage of germination (\%), evaluation with 7 days, as a function of the silicon dosages applied.

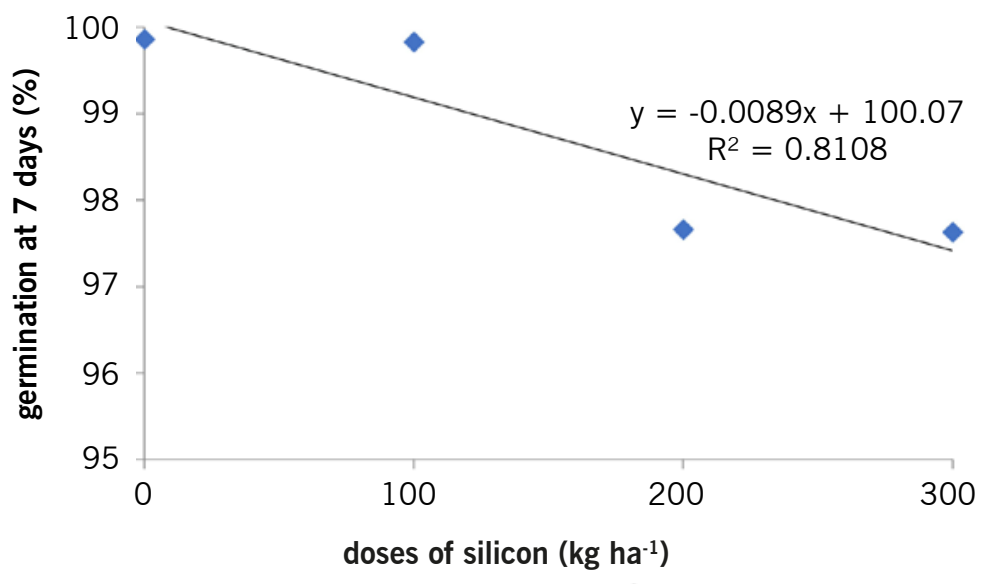

Source: Elaborated by the authors (2019).

It can be observed that data adjust to a line corn cob model, and that $81.08 \%$ of the plant's germination in this experiment occurred due to the silicon doses variation. It is also noticed that from this equivalent dosage to $100.0 \mathrm{~kg} \mathrm{ha}^{-1}$ it occurs a decline in the germination. 
It was verified that the first germination counting did not show considerable difference $(p>0,05)$, corroborating Tavares et al. (2011), who did not find remarkable differences in the first germination counting of wheat seeds covered by silicon.

Harter and Barros (2011) showed no significant difference in the first count with doses of calcium and silicone testing the application of leaves on soybeans.

Pereira et al. (2010), working with rice and testing different silicon doses in fertilization while producing seeds, noticed that for the germination parameter, there was an increase in its percentage with the increase of Si doses applied until the $1600.0 \mathrm{~kg} \mathrm{ha}^{-1}$ dosage, however, above the dosage of $3200 \mathrm{~kg}$ ha- 1 there was a decline in seed production.

To evaluate the normal seedlings verification, statistically significant differences were found $(p<0,05)$, it can be noticed the highest normal seedlings index in the equivalent dosage to $100.0 \mathrm{~kg}$ of silicon.ha-1, causing a decrease when increasing the dosages, as far which can be verified in Figure 5.

Figure 5 - Average values found for the percentage of normal seedlings as a function of the silicon dosages applied.

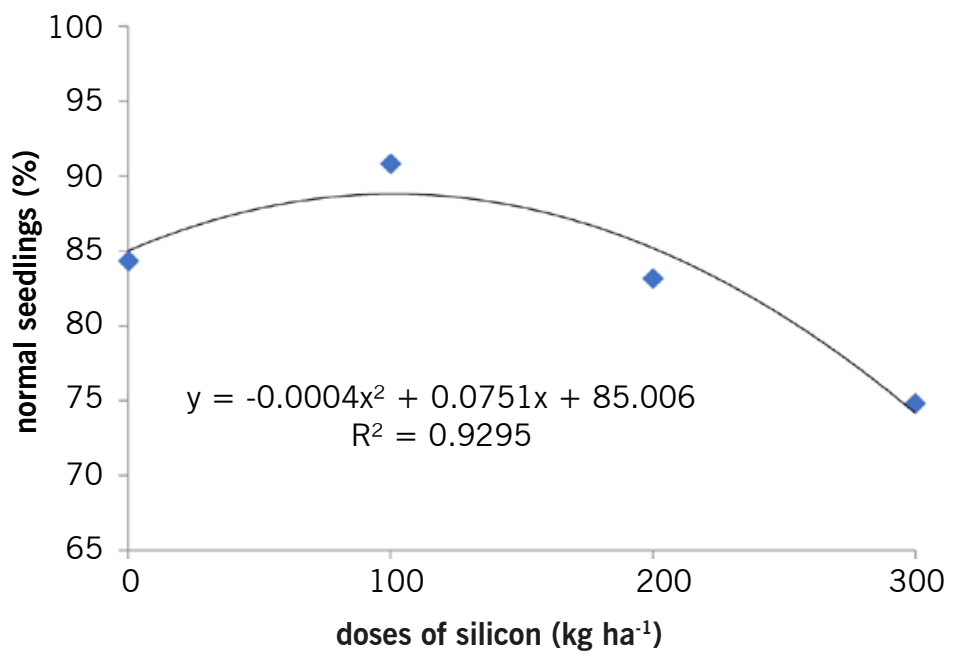

Source: Elaborated by the authors (2019).

By derivation technique, the dose that best presents normal seedlings percentage is the 93.87 kg ha-1 one.

Seedlings length is an important physiological parameter, because the higher the leaf area, the higher the area to light capture to perform the photosynthetic process, in addition to larger roots resulting in a greater dimension to explore and capture nutrients and water (TAIZ; ZEIGER, 2012).

Harter and Barros (2011) observed positive effect in the seeds quality that contained rice normal seedlings with silicone and calcium doses. But the ones fertilized with aluminum did not present a considerable result for physiological quality (LIMA et al., 2009).

\section{Conclusion}

The application of calcium silicate via leaf in this experiment increased the diameter of the stem, the weight of the ear of corn and the weight of a thousand seeds, as well as decreased the 
percentage of germination at seven days and the percentage of normal seedling without interfering with the other characteristics studied.

\section{Silício na morfometria e germinação de sementes de milho}

\section{Resumo}

Objetivou-se avaliar o desenvolvimento de planta e sementes de milho e a germinação das sementes, em resposta à aplicação de silício, em diferentes doses, via foliar. 0 delineamento experimental utilizado foi em blocos ao acaso, com quatro tratamentos de doses diferentes de silício, equivalentes à $0,0,100,0,200,0$ e 300,0 kg ha-1 de silicato de cálcio, a 22,0\%, e quatro repetições, aplicadas via foliar. Observou-se que o silício aplicado não influenciou em nenhuma das variáveis morfométricas da planta, no entanto alterou as características da espiga quanto ao peso e diâmetro, em que a melhor resposta foi observada na aplicação equivalente a $100,0 \mathrm{~kg}$ silicato-1 ha $^{-1}$. As doses de silício aplicadas não apresentaram diferenças significativas nas características morfológicas como na altura da planta, altura da primeira espiga, diâmetro de caule, número e ângulos de folhas. Foram encontradas diferenças significativas no peso de mil grãos, em que, com o aumento da dose de silício, houve o aumento no peso de mil grãos e, na germinação aos 7 dias, foi constatada que, com o aumento das doses de silicato de cálcio, ocorreu uma diminuição na porcentagem de germinação, bem como na porcentagem de plântulas normais. Conclui-se que a aplicação de silicato de cálcio via foliar aumentou o diâmetro do caule, o peso da espiga de milho e o peso de mil sementes e diminuiu o percentual de germinação em sete dias e o aparecimento de plântula normal.

Palavras-chave: Aplicação foliar. Elemento benéfico. Potencial germinativo. Qualidade. Zea Mays.

\section{References}

BALASTA, M. L. F.; PEREZ, C. M.; JULIANO, B. O.; VILLREAL, P. Effects of sílica level on some proprieties of Oriza sativa straw and hult. Canadian Journal of Botany, v. 67, n. 8, p. 2356-2363, 1989. Disponível em <https://doi.org/10.1139/b89-301>. Acesso em: 15 mar. 2019.

BALBINOT JR. A. A.; FLECK, N. G. Manejo de plantas daninhas na cultura de milho em função do arranjo espacial de plantas e características dos genótipos. Ciência Rural, v. 35, n. 1, p. 245252, jan./fev. 2005. Disponível em: <http://dx.doi.org/10.1590/S0103-84782005000100042>. Acesso em: 20 abr. 2019.

BRASIL. Ministério da Agricultura e da Reforma Agrária. Regras para análise de sementes. Brasília: SNAD/DNDV/CLAV, 1992. 365p. Disponível em <https://www.gov.br/agricultura/pt-br/assuntos/ insumos-agropecuarios/arquivos-publicacoes-insumos/2946_regras_analise_sementes.pdf $>$. Acesso em 10 fev 2019.

CAMARGO, M. S.; PEREIRA, H. S. Efeito do silicato de cálcio sobre a produção e qualidade da canade-açúcar - Usina Equipav. Congresso Brasileiro de Ciências e Solo, 29, Anais..., CD Rom, 2003.

CARVALHO, N. M.; NAKAGAWA, J. Sementes: ciência, tecnologia e produção. 4. ed. Jaboticabal: FUNEP, 2000. 588p. 
CHAVES, L. H. G.; VASCONCELOS, A. C. F. Alterações de atributos químicos do solo e do crescimento de plantas de milho pela aplicação de xisto. Revista Brasileira de Engenharia Agrícola e Ambiental, v. 10, n. 1, p. 84-88, mar. 2006. Disponível em: <http://dx.doi.org/10.1590/ S1415-43662006000100013>. Acesso em: 11 mar. 2019.

COSTA, R. R..; MORAES, J. C.; COSTA, R. R. Interação silício-imidacloprid no comportamento biológico e alimentar de Schizaphis graminum (Rond.) (Hemiptera: Aphididae) em plantas de trigo. Ciência e Agrotecnologia, v. 33, n. 02, p. 455-460, mar../apr. 2009. Disponível em: <http://dx.doi.org/ 10.1590/S1413-70542009000200014 >. Acesso em: 20 mar. 2019.

CRUZ, I.; TURPIN, F. T. Efeito da Spodoptera frugiperda em diferentes estágios de crescimento da cultura do milho. Pesquisa Agropecuária Brasileira. v. 17, n. 3, p. 355-359, marc. 1982. Disponível em: <https://seer.sct.embrapa.br/index.php/pab/article/view/15641>. Acesso em: 10 mar. 2019.

DEMÉTRIO, C. S.; FORNASIERI FILHO, D.; CAZETTA, J. O.; CAZETTA, D. A. Desempenho de híbridos de milho submetidos a diferentes espaçamentos e densidades populacionais. Pesquisa Agropecuária Brasileira, v. 43, n. 12, p. 1691-1697, dec. 2008. Disponível em: <http://dx.doi.org/10.1590/ S0100-204X2008001200008> Acesso em: 10 mar. 2019.

DEREN, C. Plant genotypes, silicon concentration and silicon related responses. In: DATNOFF, L. E.; SNYDER, G. H.; KORNDORFER, G. H. (Eds.) Silicon in Agriculture. Amsterdam: Elsevier Science. v. 1, p. 149-158, 2001.

EPSTEIN, E. Silicon in plants: Facts vs. concepts. In: DATNOFF, L. E.; SNYDER, G. H.; KORNDÖRFER, G. H. (Eds.) Silicon in Agriculture. Amsterdam: Elsevier Science. p. 1-15, 2001.

FERREIRA, R. S. Influência do silício na indução de resistência à mosca-branca Bemisia tabaci biótipo B (Genn.) (Hemiptera: Aleyrodidae) e no desenvolvimento vegetativo em dois cultivares de soja Glycine max (L.) Merril. 2006, 40 p., Dissertação (Mestrado em Entomologia) - Universidade Federal de Lavras, Lavras.

FRANZOTE, B. P.; SILVEIRA, L. S. M.; ANDRADE, M. J. B.; VIEIRA, N. M. B.; SILVA, V. M. P.; CARVALHO, J. G. Aplicação foliar de silício em feijoeiro comum. In: CONGRESSO NACIONAL DE PESQUISA DE FEIJÃO, VIII, 2005, Goiânia. Anais... Goiânia: Embrapa Arroz e Feijão, v. 2, 2005, p: 957-960.

FREITAS, L. B.; COELHO, E. M.; MAIA, S.C. M.; SILVA, T. R. B. Adubação foliar com silício na cultura do milho. Revista Ceres, Viçosa, v. 58, n. 2, p. 262-267, mar./apr. 2011. Disponível em: <http://dx.doi.org/10.1590/S0034-737X2011000200020>. Acesso em: 05 abr. 2019.

HARTER, F. S.; BARROS, A. C. S. A. Cálcio e silício na produção e qualidade de sementes de soja. Revista Brasileira de Sementes, v. 33, n.1, p. 054- 060, 2011. Disponível em: <https://doi.org/10.1590/S0101-31222011000100006>. Acesso em: 05 abr. 2019.

KORNDORDER, G. H.; DATNOFF, L. E. Papel do silício na produção da cana-de-açúcar. In: SECAP 2000, Seminário de cana de açúcar de Piracicaba, 2000, Piracicaba, cd, Julho, 2000. 
LIMA, B. D.; BARROS, A. C. S. A.; SILVA, J. L.; STOHLIRK, J.; BIN, F.; CICHELERO, T. Silicato de alumínio (Caulim) na qualidade fisiológica e produtividade de sementes de arroz (Oryza sativa L.). In: Congresso de Iniciação Científica, 18. Pelotas, 2009. Anais... Pelotas: Pró-Reitoria de Pesquisa e Pós Graduação, 2009.

LIMA FILHO, O. F.; TSAI, S. M. Crescimento e produção do trigo e da aveia branca suplementados com silício. Dourados: Embrapa Agropecuária Oeste, Boletim de Pesquisa e Desenvolvimento Embrapa Agropecuária Oeste, 41. 2007. 34 p.

MELO, S.P.; KORNDORFER, G. H.; KORNDORFER, C. M. Silicon accumulation and water déficit tolerance in Brachiaria grasses. Scientia Agricola, v. 60, p. 755-759, out/dez 2003. Disponível em: <http://dx.doi.org/10.1590/S0103-90162003000400022>. Acesso em: 05 abr. 2019.

MOLIN, R. Espaçamento entre linhas de semeadura na cultura de milho. Fundação ABC para Assistência e Divulgação Técnica Agropecuária, 2000, p. 1-2.

NERI, D. K. P.; GOMES, F. B.; MORAES, J. C.; GOES, G. B.; MARROCOS, S. T. P. Influência do silício na suscetibilidade de Spodoptera frugiperda (J.E. Smith) (Lepidoptera: Noctuidae) ao inseticida lufenuron e no desenvolvimento de plantas de milho. Ciência Rural, v. 39, n. 6, p. 1633-1638, jun. 2009. Disponível em < http://dx.doi.org/10.1590/S0103-84782009005000111>. Acesso em: 10 abr. 2019.

NUNES, A. L.; TREZZI, M. M.; DEBASTIAN, C. Manejo integrado de plantas daninhas na cultura do milho. Bragantia, v. 69, n. 2, p. 299-304, 2010. Disponível em: < http://dx.doi.org/10.1590/ s0006-87052010000200006 >. Acesso em: 10 abr. 2019.

PEREIRA JUNIOR, P.; REZENDE, P. M.; MALFITANO, S. C.; LIMA, R. K.; CORRÊA, L. V. T.; CARVALHO, E. R. Efeito de doses de silício sobre a produtividade e características agronômicas da soja [Glycine max (L.) Merrill]. Ciência e Agrotecnologia, Lavras, v. 34, n. 4, p. 908-913, jul./ago. 2010. Disponível em: <http://dx.doi.org/10.1590/S1413-70542010000400016>. Acesso em: 08 mar. 2019.

POZZA, A. A. A.; ALVES, E.; POZZA, E. A.; CARVALHO, J. G.; MONTANARI, M.; GUIMARÃES, P. T. G.; SANTOS, D. M. Efeito do silício no controle da cercosporiose em três variedades de cafeeiro. Fitopatologia Brasileira, v. 29, n. 4, p. 185-188, mar/abr 2004. Disponível em: <http://dx.doi.org/ 10.1590/S0100-41582004000200010 >. Acesso em: 02 mar. 2019.

PRADO, R. M.; KORNDORFER, G. H. Efeitos da escória de siderurgia sobre a cultura do milho (Zeamays L.) cultivados em um Latossolo Vermelho Amarelo distrófico. Científica, v. 31, p. 9-17, 2003. Disponível em: http://www.nutricaodeplantas.agr.br/site/downloads/culturas/milho_areaafim_ prado.pdf. Acesso em: 10 mar. 2019.

RAIJ, B. VAN; CANTARELLA, H.; QUAGGIO, J. A.; FURLANI, A. M. C. (Ed.). Recomendações de adubação e calagem para o Estado de São Paulo. 2. ed. rev. e atual. Campinas: Instituto Agronômico/ Fundação IAC. (Boletim Técnico, 100), 1997, 285p.

RIBEIRO, N. A.; CASA, R. T.; BOGO, A.; SANGOI, L.; WILLE, L. Incidência de podridões do colmo, grãos ardidos e produtividade de grãos de genótipos de milho em diferentes sistemas de 
manejo. Ciência Rural, Santa Maria, v. 35, n. 5, p. 1003-1009, set/out 2005. Disponível em: <http://dx.doi.org/10.1590/S0103-84782005000500004>. Acesso em: 20 mar. 2019.

SANGOI, L.; ALMEIDA, M. L.; GRACIETTI, M. A.; BIANCHET, P.; HORN, D. Maize stalk sustainability in maize hybrids from different eras as affected by plant density. Revista de Ciências Agroveterinárias, 2002. Disponível em: https://www.cabdirect.org/cabdirect/abstract/20073068420. Acesso em: 12 maio 2019.

SOUSA, J. V.; RODRIGUES, C. R.; LUZ, J. M. Q.; CARVALHO, P.C.; RODRIGUES, T. M.; BRITO, C. H. Silicato de potássio via foliar no milho: fotossíntese, crescimento e produtividade. Bioscience Journal. v. 26, n. 4, p. 503-513, jul/ago 2010. Disponível em: <http://www.seer.ufu.br/index.php/ biosciencejournal/article/view/7148>. Acesso em: 15 abr. 2019.

TAIZ L.; ZEIGER, E. Fisiologia Vegetal. 5. Ed. Porto Alegre, Artmed, 2012, 95 p.

TAVARES, L. C.; BRAZ, H. S.; TUNES, L. M.; FONSECA, D. A. R.; BARROS, A. C. S. A. Desempenho de sementes de trigo recobertas com silício. In: $20^{\circ}$ Congresso de Iniciação Científica, II amostra científica, Pelotas. Anais... UFPI, 2011, p. 12-15.

TEODORO, P. E.; RIBEIRO, L. P.; CORREA, C. C. G.; TORRES, F. E. Desempenho de híbridos de milho sob aplicação foliar de silício no cerrado sul-mato-grossense. Bioscience Journal, supplement 1 , v. 30, n. 3, suplemento, p. 224-231, 2014. Disponível em: <http://www.seer.ufu.br/index.php/ biosciencejournal/article/view/18009>. Acesso em: 12 abr. 2019.

VASQUEZ, G. H.; ARF, O.; SARGI, B. A.; PESSOA, A. C.O. Influência do tamanho e da forma da semente de milho sobre o desenvolvimento da planta e a produtividade de grãos. Bioscience Journal., Uberlândia, v. 28, n. 1, p. 16-24, jan./fev. 2012. Disponível em: <http://www.seer.ufu.br/index.php/ biosciencejournal/article/view/11671>. Acesso em: 12 abr. 2019.

Received in: September 2, 2019

Accepted in: November 13, 2019 